\title{
Antimicrobial activity of Luma apiculata against resistant strains of Staphylococcus aureus and Klebsiella pneumoniae
}

Favián F Treulen ${ }^{1,2,3^{*}}$, Gonzalo E Salcedo ${ }^{1}$, Felipe I Garrido ${ }^{1}$, Cristian E Morales ${ }^{1}$, Erwin $\mathrm{Paz}^{2,3}$ and Ricardo Felmer ${ }^{2,4}$

1. School of Medical Technology, Faculty of Science, Universidad Mayor-Chile

2. Department of Agricultural Sciences and Natural Resources, Faculty of Agriculture and Forestry Sciences,

Universidad de La Frontera-Chile

3. UWA Institute of Agriculture M082, University of Western Australia-Australia

4. Laboratory of Reproduction, Centre of Reproductive Biotechnology (CEBIOR-BIOREN), Faculty of Medicine, Universidad de La Frontera-Chile

*Corresponding author's email: favian.treulen@ mayor.cl

Citation

Favián F Treulen, Gonzalo E Salcedo, Felipe I Garrido, Cristian E Morales, Erwin Paz and Ricardo Felmer. Antimicrobial activity of Luma apiculata against resistant strains of Staphylococcus aureus and Klebsiella pneumoniae. Pure and Applied Biology. Vol. 8, Issue 3, pp1962-1974. http://dx.doi.org/10.19045/bspab.2019.80140 \begin{tabular}{llll}
\hline \hline Received: 02/05/2019 & Revised: 10/07/2019 & Accepted: 31/07/2019 & Online First: -7/08/2019
\end{tabular}

\section{Abstract}

Bacterial resistance is the mechanism through which the bacteria can decrease the action of antimicrobial agents. Studies have reported an antimicrobial action of Luma apiculata, however, there are no in vitro studies demonstrating the effect of this plant against multidrug-resistant bacteria. The objective of this study was to explore the antimicrobial properties of alcoholic extract of Luma apiculata against standard multi-resistant bacterial pathogens. Multidrug-resistant strains of Staphylococcus aureus ATCC 43300 (MRSA) and Klebsiella pneumoniae ATCC BAA 1705 (CRKP) were incubated independently for $72 \mathrm{~h}$ at $37^{\circ} \mathrm{C}$ with different concentrations (1-10,000 $\mu \mathrm{g} / \mathrm{mL}$ ) of alcoholic extract of Luma apiculata. The growth curve was studied up to 72 hours. The minimum inhibitory concentration (MIC) was determined by broth macrodilution method. The agar diffusion method was used to examine bacteriostatic activity and bactericidal activity was evaluated by a commercial kit and analyzed by flow cytometry. Analyses of chromatographic data, as well as mass spectrometry, were performed to determine the main compounds present in the extracts. Luma apiculata leaves extracts showed bactericidal activity and was effective attenuating growth in both bacterial strains. Thus, Luma apiculata could represent a natural alternative against multidrug-resistant bacterial strains. However, further studies should be undertaken to test their clinical utility.

Keywords: Antimicrobial activity; Arrayan; Flavonoids; Medicinal plants; Multiresistant bacteria Introduction

Antimicrobial resistance (AR) represents an important health issue that requires worldwide attention. The importance of AR has grown gradually becoming a global issue mainly because it can be transmitted between different hosts and rapidly spreads between continents $[1,2]$. In recent years, antibioticresistant pathogens from the ESKAPE group (Enterococcus faecium, Staphylococcus 
aureus, Klebsiella pneumoniae, Acinetobacter baumanii, Pseudomonas aeruginosa, and Enterobacter spp.) have been frequently detected in patients, representing an emerging health threat [3]. The emergence of antibiotic-resistant forms of pathogenic $S$. aureus is a worldwide problem in clinical medicine [4]. Furthermore, methicillin-resistant Staphylococcus aureus (MRSA) remains as a major global cause of health-care-associated infections [5]. Klebsiella pneumoniae is an opportunistic pathogen in immunocompromised individuals that causes a wide range of infections, including pneumonia, urinary tract infection, bacteremia, and meningitis [6]. In the last two decades, strains confirmed to produce Klebsiella pneumoniae carbapenemase (KPC) have been attributed to numerous nosocomial infections worldwide.

Despite the fact that Klebsiella pneumoniae is the main producer of $\beta$-lactamase type KPC, other species such as Enterobacteriaceae (Klebsiella oxytoca, Enterobacter spp., Escherichia coli, Salmonella spp., Citrobacter freundii, and Serratia spp.) and Pseudomonas aeruginosa also produce enzymes that confer resistance to $\beta$-lactamic agents $[7,8]$.

In recent years, there has been an increased interest in studying the antibacterial properties of natural sources such as plants. Antimicrobial compounds from these natural sources, including essential oils or plant extracts, are currently available for their use in alternative therapies [9].

A number of studies from different plant species have shown antibacterial properties [10-12]. The arrayan (Luma apiculata (DC.) Burret) is a Chilean myrtle that has been used in traditional medicine [13] . The medicinal properties of Myrtle leaves include aromatic, astringent, balsamic and anti-inflammatory actions [14]. Previous reports have shown an inhibitory activity of the xanthine oxidase enzyme by Paraguayan and Chilean Myrtaceae species commonly used in folk medicine to treat gout [15] and also as astringent [16]. Leaves of Luma apiculata are used to treat diarrhea, dysentery, and ingestion [17]. In addition, Simirgiotis et al. [18] described the phenolic compounds pattern, highlighting its high polyphenolic contents and demonstrated the high antioxidant capacity in leaves of Luma apiculate.

Despite the traditional use of Luma apiculata, few investigations have been performed to prove its therapeutic effect as anti-infective agent to establish potential medicinal activity against persistent infections. The objective of this study was to explore the antimicrobial properties of alcoholic extracts of Luma apiculata leaves against standard multiresistant bacterial pathogens.

\section{Materials and methods}

Chemicals and reagents

Bacteria were grown in Mueller-Hinton broth medium (Oxoid, Madrid, España) and Mueller-Hinton agar plate (Biomerieux, Marcy-l'orme, France). Antimicrobial disk reagents: vancomycin E-test, cefoxitin (30 $\mu \mathrm{g})$ (Biomerieux, Marcy-l’orme, France), gentamicin $(10 \mu \mathrm{g})$ and meropenem $(10 \mu \mathrm{g})$ were obtained from Mast Diagnostics (Merseyside, UK). LIVE/DEAD®BacLight bacterial viability Kit was purchased from Molecular Probes (Eugene, OR, USA) and used in accordance with the manufacturer's instructions.

\section{Collection and preparation of plant samples}

Fresh plants were collected from different geographical areas of the Araucania region $\left(37^{\circ} 35^{\prime}-39^{\circ} 37^{\prime} \mathrm{S}, 90^{\circ} 50^{\prime} \mathrm{W}\right)$ located in the Southern part of Chile during September 2017. L. apiculata was identified according to Herbal Medicines guide [14]. And confirmed by HERBARIO CONC (Botanical Department, University of Concepción, Chile). The voucher number of the sample is 
CONC 186475. Fresh leaves were washed with sterilized water and allowed to dry in air. Dried leaves were homogenized to a fine powder using a pestle and mortar and stored in a sterile bottle at $4{ }^{\circ} \mathrm{C}$ for further analysis.

\section{Sample preparation}

Ten grams of dried leaves powder ( $L$. apiculata) were extracted with $40 \mathrm{~mL}$ of $95 \%$ methanol and mixed on a rotary shaker to 170 $\mathrm{rpm}$ for $24 \mathrm{~h}$ at $30{ }^{\circ} \mathrm{C}$. The extracts were filtered using Whatman filter paper No. 1 and then concentrated using a rotary vacuum evaporator (RE-52AA, Hitech-Lab) at $40^{\circ} \mathrm{C}$. The alcoholic extract had a concentration of $815.2 \mathrm{mg} / \mathrm{mL}$ dry material, which was dissolved with $1 \mathrm{~mL}$ DMSO $0.01 \%$ in distilled water. The extracts obtained were stored at $-20{ }^{\circ} \mathrm{C}$ in an air tight bottle for further investigation.

\section{Microorganisms}

The following strains were obtained from the American Type Culture Collection (ATCC; Rockville, MD) and used in this study: Methicillin and oxacillin-resistant Staphylococcus aureus (ATCC ${ }^{\circledR} 43300^{\mathrm{TM}}$ ) and Klebsiella pneumoniae (ATCC ${ }^{\circledR}$ BAA$1705^{\mathrm{TM}}$ ) carbapenemase-positive. According to the American Type Culture Collection (ATCC) Klebsiella pneumoniae (ATCC ${ }^{\circledR}$ BAA- $1705^{\mathrm{TM}}$ ) is resistant to: Amoxicillin/Clavulanic Acid, Piperacillin, Ampicillin, Ampicillin/Sulbactam, Cefazolin, Cefoxitin, Ceftazidime, Ceftriaxone, Cefepime, Meropenem, Ertapenem, Imipenem, Ciprofloxacin, Levofloxacin, Amikacin, Nitrofurantoin, Aztreonam, Trimethoprim/Sulfamethoxazole and sensitive to Gentamycin. Both strains were reconstituted according to the manufacturer's recommendations and incubated at $37^{\circ} \mathrm{C}$ for $24 \mathrm{~h}$. The purity of the cultures was confirmed by Gram staining.

Proof of resistance and sensitivity to antibiotics

Although ATCC has tested every one of the strains to verify species, KPC production, and multidrug resistance, we confirmed the relative resistance of MRSA and CRKP strains using disk diffusion method with cefoxitin $(30 \mu \mathrm{g})$ and meropenem $(10 \mu \mathrm{g})$, and sensitivity with vancomycin and gentamicin $(10 \mu \mathrm{g})$, respectively (Figure 1). The agar plates were incubated at $37^{\circ} \mathrm{C}$ for $24 \mathrm{~h}$.

\section{Effect of plant extract on bacterial growth curve}

To evaluate the effect of plant extracts on bacterial growth curve, different concentrations of extract were prepared (1, 10, 100, 1000 and $10000 \mu \mathrm{g} / \mathrm{mL})$. All concentrations of both bacterial strains were incubated at an initial concentration of 0.5 McFarland $\left(1.5 \times 10^{8}\right.$ cells per $\left.\mathrm{cm}^{3}\right)$. Bacterial concentrations and bacterial growth rates were calculated by measuring the optical density (OD) at the wavelengths of $600 \mathrm{~nm}$ at $0,3,6,24,48$ and $72 \mathrm{~h}$ (OD of 0.1 corresponds to a concentration of $1.5 \times 10^{8}$ cells per $\mathrm{cm}^{3}$ ). Bacterial strains without plant extracts were used as controls.

\section{Determination of minimum inhibitory} concentration (MIC) of plant extracts

For the determination of MIC, the broth macrodilution susceptibility assay was performed, according to standard M100-S9 of the National Committee for Clinical Laboratory Standards [19]. Six dilutions series of plant extracts were prepared from 1 to $10,000 \mu \mathrm{g} / \mathrm{mL}$, into test tubes containing $10 \mathrm{~mL}$ Mueller Hinton broth medium. The bacterial broth cultures were adjusted to 0.5 McFarland turbidity standards and added into each of the test tubes. The medium containing a mixture of bacteria and extracts was incubated at $37^{\circ} \mathrm{C}$ for $24 \mathrm{~h}$ in a shaker water bath. Bacterial strains without plant extracts were used as controls.

\section{Antimicrobial susceptibility testing}

The antibacterial activity assay of plant extracts was developed using the agar diffusion method. The MRSA and CRKP strains were performed by Kirby-Bauer 
method on Muller Hinton agar plates. Whatman filter No.1 paper discs were soaked with $10 \mu \mathrm{L}$ of extract in concentrations of 1 , $10,100,1000$ and $10,000 \mu \mathrm{g} / \mathrm{mL}$ and air dried before the assay [20]. Cultures were incubated at $37^{\circ} \mathrm{C}$ for $24 \mathrm{~h}$ prior to testing, using the criteria of standard zone sizes of inhibition according to Clinical and Laboratory Standards Institute (CLSI) guidelines [19]. After the period of incubation, the antimicrobial activity was measured in millimeters of the zone of inhibition and categorized as sensitive or resistant.

\section{Bacteriostatic activity of plant extracts}

To estimate the bacteriostatic activity of alcoholic extracts of $L$. apiculata, each Mueller Hinton broth tubes used to calculate the MIC was transferred onto the surface of Muller Hinton agar plates and incubated at 37 ${ }^{\circ} \mathrm{C}$ for $24 \mathrm{~h}$. Inhibition of bacterial growth was considered as bacteriostatic activity of that extract.

\section{Bactericidal activity of plant extracts}

To assess the effect of plant extracts on bactericidal activity, concentrations of 100 , 1,000 and $10,000 \mu \mathrm{g} / \mathrm{mL}$ of each extract were prepared. Bacterial strains without plant extracts were used as controls. The bacterial strains were incubated at an initial concentration of $0.5 \mathrm{McF}$ arland $\left(1.5 \times 10^{8}\right.$ cells per $\mathrm{cm}^{3}$ ) at $37{ }^{\circ} \mathrm{C}$ for $72 \mathrm{~h}$. Direct measurement of bactericidal activity was assessed by using LIVE/DEAD ${ }^{\circledR}$ BacLight bacterial viability Kit (Molecular Probes, Eugene, OR, USA). This assay uses twocolor fluorescences, which differs in the ability to penetrate cell membranes. The green fluorescent $\mathrm{SYTO}^{\circledR} 9$ stains the nucleic acids of both living and dead bacteria, while Propidium Iodide (red) labels the nucleus of bacteria with damaged and leaky membranes. The fluorescence analysis was performed using a FACSCanto TM II flow cytometer (BD Biosciences, San Jose, CA, USA). Data were acquired and analysed with the software
FACSDiva version 6.1.3 (Becton, Dickinson and Company, BD Biosciences, San Jose, CA, USA). At least 10,000 events were acquired for each sample. Fluorochrome excitation was carried out using a $488 \mathrm{~nm}$ argon-ion laser. Green fluorescence was collected with a 530/30 nm bandpass filter and orange fluorescence through a 585/42 nm bandpass filter, both were analyzed on logarithmic scales.

\section{HPLC-UV - ESI MS/MS analysis}

The extracts were analyzed by using HPLCUV- ESI/MS/MS system consisting of a Shimadzu Prominence LC-20AD liquid chromatograph (Shimadzu, Milan, Italy) with an UV/VIS detector coupled to a 3200 QTRAP Hybrid Quadrupole-Linear Ion Trap Mass Spectrometer (Applied Biosystems, AB Sciex, Foster City, CA, USA) equipped with an Electrospray ionization (ESI) Turbo ionspray interface. The chromatographic separation was carried out using an Inertsil ODS-3 C18 column (2.1 x $150 \mathrm{~mm}, 3 \mu \mathrm{m})$ with a sample injection volume of $10 \mu \mathrm{L}$. The flow rate was set at $0.25 \mathrm{~mL} / \mathrm{min}$ and the column was maintained at $25{ }^{\circ} \mathrm{C}$. The working wavelength of the UV/VIS detector was performed at $\lambda=280 \mathrm{~nm}$. The control of components of the HPLC system, data collection and analysis were carried out by Analyst $^{\circledR} \quad$ 1.5.1 software (Applied Biosystems/AB Sciex). The mobile phase consisted of $0.1 \%(\mathrm{v} / \mathrm{v})$ formic acid in water (A) and $0.1 \%(\mathrm{v} / \mathrm{v})$ formic acid in acetonitrile (B). The gradient program was used as follows with a total analysis time of $40 \mathrm{~min}$ : 80\% A (0-1 min), 78\% A (20 min), 50\% A (30 min), 0\% A (31-35min), and 80\% B (36$40 \mathrm{~min})$.

The analyses were performed using the Turbo $\mathrm{V}^{(\mathrm{R})}$ ion spray in positive and negative ionization mode by using the information dependent acquisition (IDA) method editor. Enhanced MS (EMS) spectra were acquired between $m / z$ 100-1,000 at scan speed of 1,000 $\mathrm{Da} / \mathrm{s}$. Enhanced production ion (EPI) spectra 
were acquired between $\mathrm{m} / \mathrm{z}, 50-1,000$ at scan speed of $4,000 \mathrm{Da} / \mathrm{s}$ which provided a fragment footprint of compounds of interest.

\section{Statistical analysis}

All trials were repeated at least five times. The experiments were carried out in duplicate and results were expressed as mean \pm S.D. Statistical evaluation was performed with the Prism 6 software package (GraphPad, La Jolla, CA, USA), applying D`Agostino test to assess Gaussian distribution. Analysis of variance (ANOVA) was applied to determine the effect produced by different concentrations of the plant extracts and Bonferroni post hoc test was used to perform multiple comparisons. Statistical significance was established for $\mathrm{P}$ $<0.05$.

\section{Results}

Proof of resistance and sensitivity to antibiotics

As shown in (Figure 1), inhibition area of MRSA-isolates was approximately $17 \mathrm{~mm}$ for $30 \mu \mathrm{g}$ cefoxitin disk (resistant $\leq 21 \mathrm{~mm}$ ) (Figure 1Ai). An elliptical zone was obtained against the MRSA strain with a vancomycinMIC of $0.75 \mu \mathrm{g} / \mathrm{mL}$ (sensitive $\mathrm{MIC} \leq 2$ $\mu \mathrm{g} / \mathrm{mL}$ ) (Figure 1Aii). Furthermore, isolates of CRKP had an inhibition area of $14 \mathrm{~mm}$ for $10 \mu \mathrm{g}$ meropenem disk (resistant $\leq 19 \mathrm{~mm}$ ) (Figure 1Biii) and $22 \mathrm{~mm}$ for $10 \mu \mathrm{g}$ gentamicin disk (sensitive $\geq 15 \mathrm{~mm}$ ) (Figure 1Biv).

\section{Effect of plant extracts on bacterial growth curve}

Description of the bacterial growth curves is shown in (Figure 2). Exponential growth phase and stationary phase were observed early at $24 \mathrm{~h}$, and $72 \mathrm{~h}$, for $S$. aureus and $K$. pneumoniae respectively. The bacterial growth of $S$. aureus and $K$. pneumoniae was diminished 6-fold by the addition of alcoholic extract of L. apiculata, compared to the profiles without any plant extract $(P<$ 0.0001). L. apiculata did not alter the growth curve of $S$. aureus between concentrations of
$1 \mu \mathrm{g} / \mathrm{mL}$ to $100 \mu \mathrm{g} / \mathrm{mL}$ dry material, compared with the control group $(P>0.05)$. Contrary, we observed that growth curves of $S$. aureus were reduced significantly with concentrations of $1,000 \mu \mathrm{g} / \mathrm{mL}$ and 10,000 $\mu \mathrm{g} / \mathrm{mL}$ dry material after $6 \mathrm{~h}$ and $48 \mathrm{~h}$ of incubation respectively $(P<0.001)$, compared with the control group (Figure 2A). Treatment with an alcoholic extract of $L$. apiculata against $K$. pneumoniae revealed no significant difference among dry material concentrations of $1 \mu \mathrm{g} / \mathrm{mL}$ to $100 \mu \mathrm{g} / \mathrm{mL}$ compared to the untreated control $(P>0.05)$. However, significant differences were found after $6 \mathrm{~h}$ with $10,000 \mu \mathrm{g} / \mathrm{mL}$ and after $24 \mathrm{~h}$ with $1,000 \mu \mathrm{g} / \mathrm{mL}$ of dry material compared to the untreated control $(P<0.001$; Figure 2B).

\section{Determination of minimum inhibitory concentrations}

Determination of MIC was not possible due to the appearance of intense turbidity during the test conditions for all plant extracts. The same growth inhibitory activity can be observed with the agar diffusion method, which is adequate to assess the possible antimicrobial activity of natural extracts [21]. Sensitivity analysis to extracts by the agar diffusion method

A clear circular area of inhibition was obtained from the agar diffusion test. The bacterial growth inhibition for $S$. aureus using $30 \mu \mathrm{g}$ cefoxitin disc (Figure 3F) as resistant control, was approximately $16 \mathrm{~mm}$ (specific breakpoint $\leq 21 \mathrm{~mm}$ for resistant and $\geq 22 \mathrm{~mm}$ for susceptible) and using vancomycin-MIC (Figure 3G) as sensitive control, it was $0.75 \mu \mathrm{g} / \mathrm{mL}$ (specific breakpoint $\leq 2 \mu \mathrm{g} / \mathrm{mL}$ sensitive). When we evaluated growth inhibitory activity of plant extract against $S$. aureus, only concentrations of $1,000 \mu \mathrm{g} / \mathrm{mL}$ and $10,000 \mu \mathrm{g} / \mathrm{mL}$ showed a significative inhibitory activity (Figures 3A, $\mathrm{B}, \mathrm{C}$ respectively). At the concentration of $1,000 \mu \mathrm{g} / \mathrm{mL}$ an inhibition zone of $9 \mathrm{~mm}$ was observed (Figure 3D). The maximum 
inhibition zone $(14 \mathrm{~mm})$ was detected at the concentration of $10,000 \mu \mathrm{g} / \mathrm{mL}$ (Figure 3E). The bacterial growth inhibition for $K$. pneumoniae using $10 \mu \mathrm{g}$ meropenem disc (Figure 4F) as resistant control, was approximately $15 \mathrm{~mm}$ (specific breakpoint $\leq 19 \mathrm{~mm}$ for resistant and $\geq 22 \mathrm{~mm}$ for susceptible) and using $10 \mu \mathrm{g}$ gentamicin disc (Figure 4G) as sensitive control, it was approximately $21 \mathrm{~mm}$ (specific breakpoint $\geq 15 \mathrm{~mm}$ sensitive). Discs with concentrations of 1,10 and $100 \mu \mathrm{g} / \mathrm{mL}$ were found to be resistant, showing no signs of inhibition (Figure 4A, B, C respectively). At the higher concentrations of 1,000 and $10,000 \mu \mathrm{g} / \mathrm{mL}$ a small inhibition zone $(7 \mathrm{~mm})$ was observed (Figures 4D and E, respectively).

\section{Bacteriostatic activity of plant extracts}

Bacteriostatic activity of $L$. apiculata was only observed against MRSA. When concentrations of $10,000 \mu \mathrm{g} / \mathrm{mL}$ were challenged against MRSA an inhibition of the development of bacterial colonies was observed (Figure 5F).

\section{Bactericidal activity of plant extract}

The bactericidal activity of plant extracts against $S$. aureus ATCC 43300 (Figure 6A) and $K$. pneumoniae ATCC BAA 1705 (Figure 6B) was statistically significant at the concentrations of 1,000 and $10,000 \mu \mathrm{g} / \mathrm{mL}$ compared to control. The bactericidal activity detected in the alcoholic extract of $L$. apiculata against $S$. aureus ATCC 43300 was significantly more effective than for $K$. pneumoniae ATCC BAA 1705 at the concentration of 1,000 and $10,000 \mu \mathrm{g} / \mathrm{mL}$.

HPLC-UV- ESI MS/MS analysis

Nine flavonoids, including (+)-epicatechin, myricetin, myricetin-3-glucoside, quercetin, Quercetin-3-glucoside, isorhamnetin, Quercetin-3-Rhamnoside (Quercitrin), Isorhamnetin-3-Rutinoside, Isorhamnetin-3Glucoside were identified from the ethanolic extract of L. apiculata. All of them classified as flavonoid compounds. The profile of the principal compounds detected in the ethanolic extract of L. apiculata is shown in (Table 1).

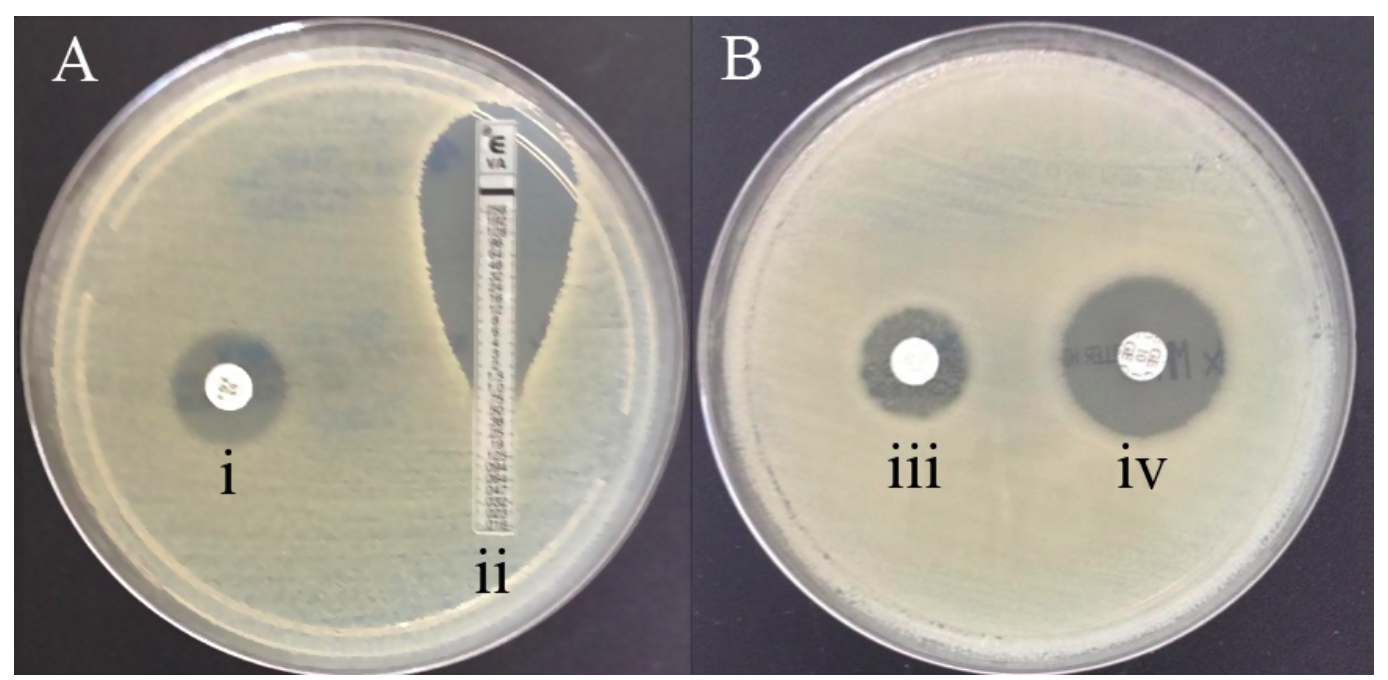

Figure 1. Disc agar-diffusion method (A) Culture of MRSA; (B) Culture of CRKP. Disks: i) Resistance test of $S$. aureus to cefoxitin (FOX disc contain $30 \mu \mathrm{g}$ ); ii) Sensitivity test of $S$. aureus to vancomycin E-test MICs (VA); iii) Resistance test of $K$. pneumoniae to meropenem (MEM disc contain $10 \mu \mathrm{g}$ ); iv) Sensitivity test of $K$. pneumoniae to gentamycin (GE disc contain $10 \mu \mathrm{g}$ ) 

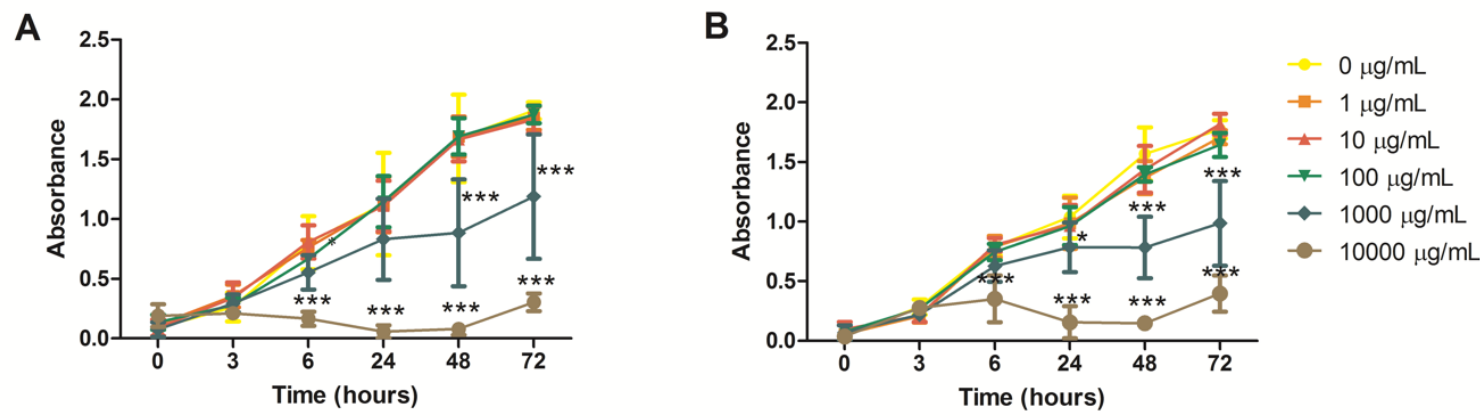

Figure 2. Bacterial growth showing the mean \pm SD on the different concentrations of plant extracts versus time curve. (A) Growth profiles of $S$. aureus in alcoholic extracts of $L$. apiculata. (B) Growth profiles of $K$. pneumoniae in alcoholic extracts of $L$. apiculata. Twoway ANOVA test was used to examine any statistically significant differences. Levels of statistical significance ${ }^{*} \mathbf{P}<0.05,{ }^{* *} \mathbf{P}<0.01,{ }^{* * *} \mathbf{P}<0.001$

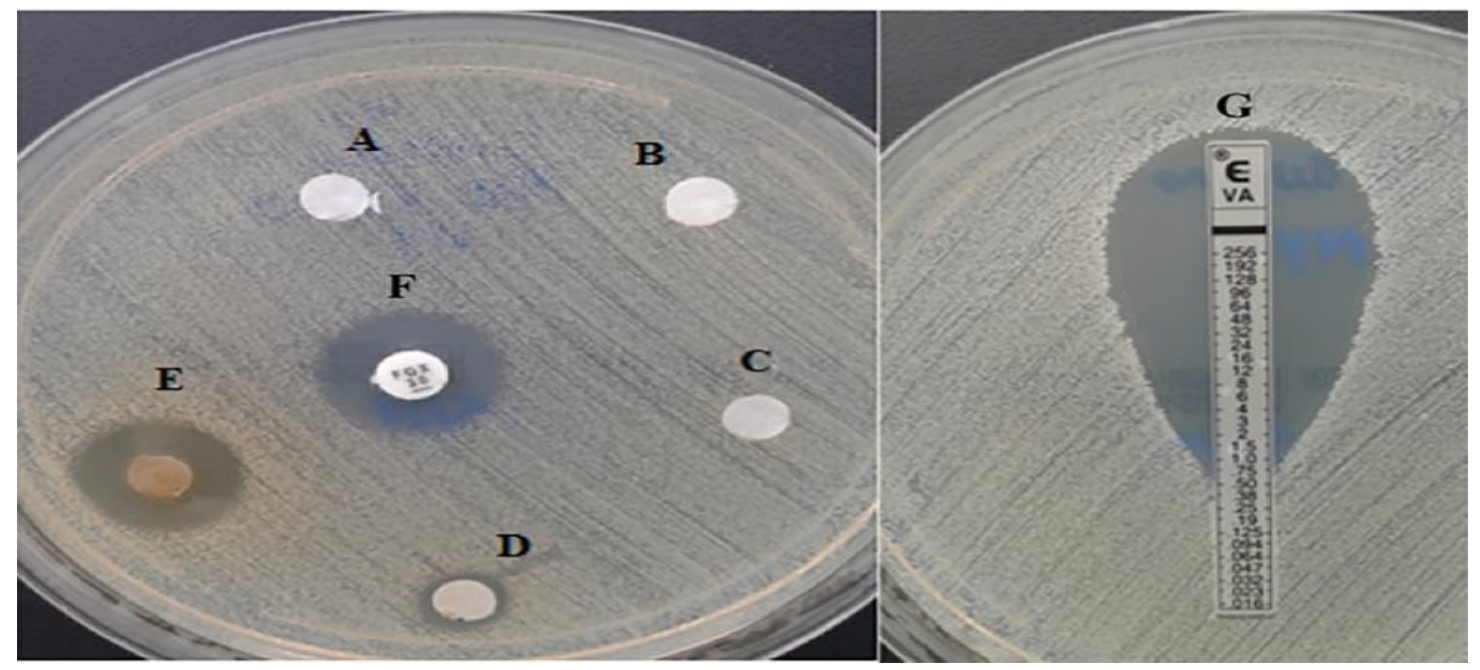

Figure 3. Agar diffusion assay using S. aureus ATCC 43300. Cefoxitin disk (FOX) and vancomycin E-test were used for detection of resistance and sensitivity, respectively. $L$. apiculata extracts at concentrations of $1(\mathrm{~A}), 10(\mathrm{~B}), 100(\mathrm{C}), 1,000(\mathrm{D}), 10,000(\mathrm{E}) \mu \mathrm{g} / \mathrm{mL},(\mathrm{F})$ FOX and (G) vancomycin E-test 


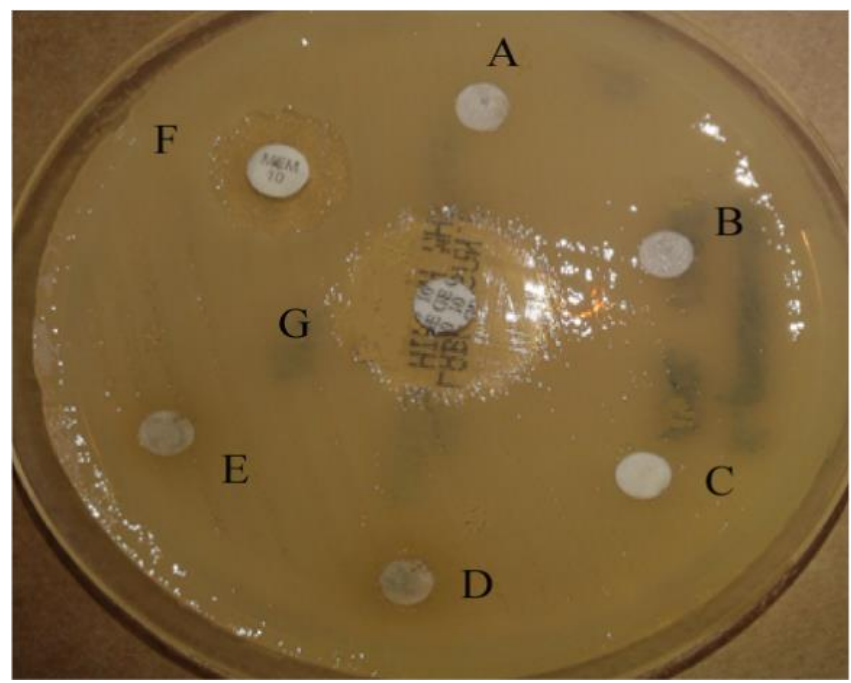

Figure 4. Agar diffusion assay using $K$. pneumoniae ATCC BAA 1705. Meropenem disk (MEM) and gentamicin disk (GE) were used for detection of resistance and sensitivity, respectively. L. apiculata extracts at concentrations of $1(\mathrm{~A}), 10(\mathrm{~B}), 100(\mathrm{C}), 1,000(\mathrm{D}), 10,000$ (E) $\mu \mathrm{g} / \mathrm{mL}$, meropenem disc (F) and gentamicin disc (G)
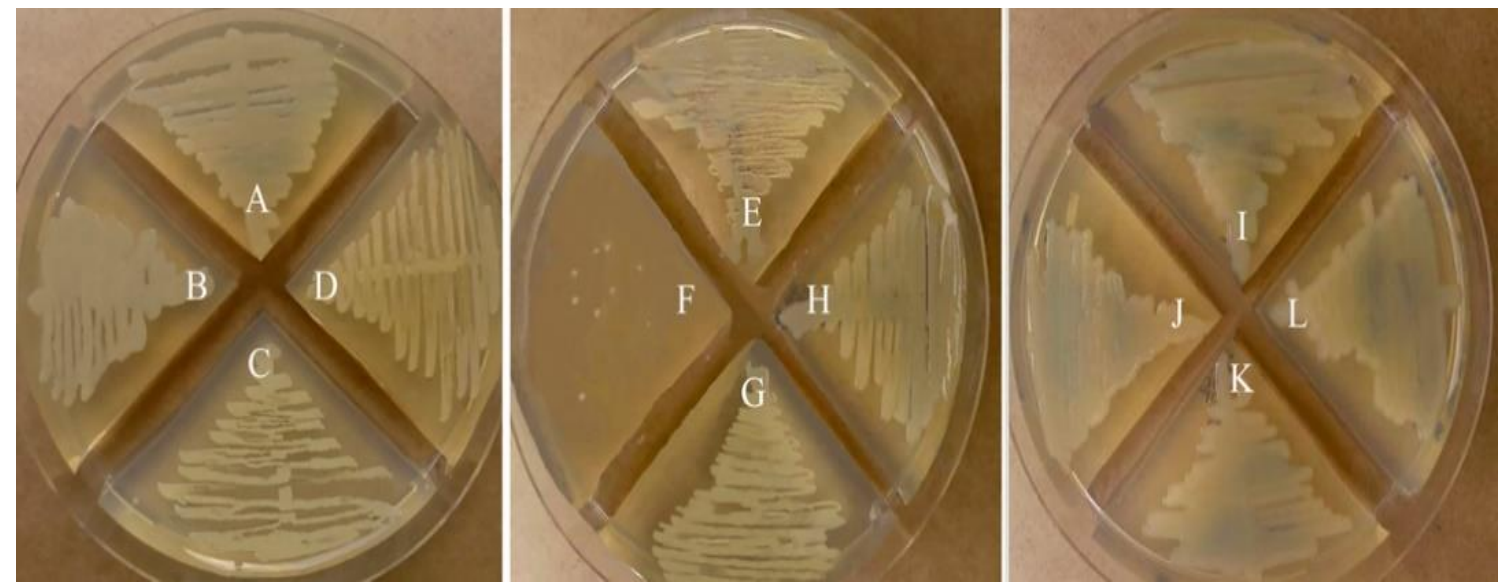

Figure 5. Bacteriostatic activity of different concentrations of vegetable extracts against $S$. aureus: (A), $0 \mu \mathrm{g} / \mathrm{mL}$; (B) $1 \mu \mathrm{g} / \mathrm{mL}$; (C) $10 \mu \mathrm{g} / \mathrm{mL}$; (D) $100 \mu \mathrm{g} / \mathrm{mL}$; (E) 1,000 $\mu \mathrm{g} / \mathrm{mL}$; (F) $10,000 \mu \mathrm{g} / \mathrm{mL}$ and $K$. pneumoniae: (G) $0 \mu \mathrm{g} / \mathrm{mL}$; (H) $1 \mu \mathrm{g} / \mathrm{mL}$; (I) $10 \mu \mathrm{g} / \mathrm{mL}$; (J) $100 \mu \mathrm{g} / \mathrm{mL}$; (K) $1,000 \mu \mathrm{g} / \mathrm{mL}$; (L) $10,000 \mu \mathrm{g} / \mathrm{mL}$ 

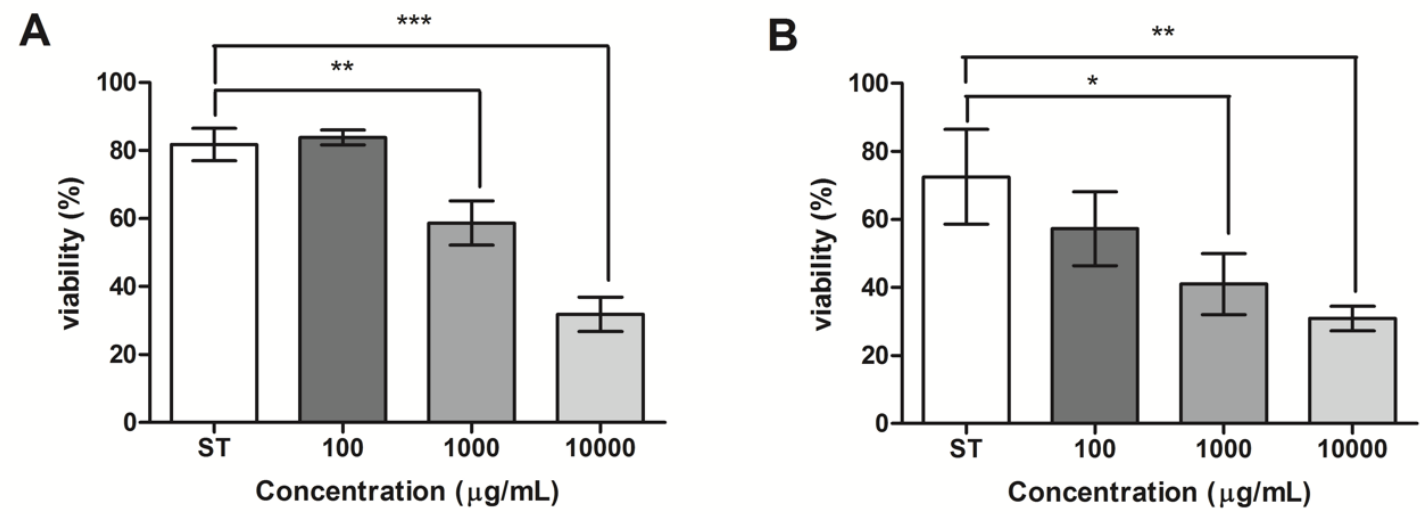

Figure 6. Bactericidal effect with different plant extract concentrations on viability of MRSA and CRKD. The experiment was repeated five times in parallel to different control antibiotics. Bars represent mean \pm SD. One-way ANOVA test was used to examine any statistically significant differences. Levels of statistical significance ${ }^{*} \mathrm{P}<0.05,{ }^{* *} \mathrm{P}<0.01$, ${ }^{* * *} \mathbf{P}<0.001$. (A) Alcoholic extract of Luma apiculata against MRSA strain. (B) Alcoholic extract of $L$. apiculata against CRKD strain

\section{Discussion}

Antimicrobial resistance has turned into a severe health threat concern worldwide promoting scientific interventions and encourages to find new therapeutic alternatives. In March of 2015, 36 novel broad-spectrum antimicrobials that can treat serious bacterial infections are under clinical trials [22]. Plant species have recently received attention for their antimicrobial compounds usually stored as secondary metabolites [11]. In our study, an alcoholic extract from leaves of Luma apiculata was used. The alcoholic extraction is more effective because the concentration required to inhibit the bacteria growth is lower, and the bacterial inhibitory effect is stronger than the aqueous extract [23]. Although flavonoids are soluble in water, better recovery is achieved by using polar solvents such as ethanol, obtaining a greater amount of phenolic and flavonoid compounds which are attributed with antibacterial activity [24].

Luma apiculata showed antimicrobial activity only with the highest concentrations used in this study. We did not test for cytotoxicity at these concentrations but there are no reports of cytotoxicity of these concentrations in somatic cells. In terms of selectivity, a number of studies have shown that non-cancer cells are less sensitive to plant extracts than tumor cell lines, which can be explained by the growth rate of tumor cells compared with non-cancer cells [25]. In addition, a toxicity study suggested that myricetin, a compound present in $L$. apiculata extract, does not exert cytotoxicity towards normal breast epithelial MCF10A cells, hence, researchers concluded that the compound is safe for further in vivo studies [26]. This strongly suggests that selective toxicity of $L$. apiculata is an important factor that should be investigated.

The results of this study show that plant extract inhibited bacterial growth with the highest concentrations used. The inhibitory action of bacterial growth can be due to the presence of monoterpenes in the plant [27]. These organic compounds exert a protective function against biotic attacks such as 
infections caused by viral, bacterial and fungal pathogens. Possible mechanisms of action may be due to the lipid bilayer disruption by the terpenes $[12,28]$.

Table 1. Identification of phenolic compounds in Luma apiculata leaves by an HPLC/UVESI MS MS system. The analyses were performed using the Turbo $V(R)$ ion spray in positive (A) and negative (B) ionization mode

A

\begin{tabular}{|c|c|c|c|c|c|c|c|c|c|c|c|}
\hline \multirow{2}{*}{\begin{tabular}{|r} 
Compounds \\
Procyanidin B1 \\
\end{tabular}} & \multirow{2}{*}{$\begin{array}{c}\text { Retention } \\
\text { Time } \\
\text { (min) }\end{array}$} & \multirow{2}{*}{$\begin{array}{c}\begin{array}{c}{[\mathbf{M}+\mathbf{H}]^{+}} \\
(\mathrm{m} / z)\end{array} \\
579\end{array}$} & \multicolumn{8}{|c|}{ Fragments (MS2) } & \multirow[t]{2}{*}{ Class } \\
\hline & & & 579 & 561 & 427 & 409 & 291 & 247 & & & \\
\hline (+)-Epicatechin & 50,7 & 291 & 291 & 273 & 249 & 207 & 179 & 161 & 147 & & Flavonoid \\
\hline Myricetin-3-glucoside & 56,2 & 481 & 481 & 319 & 273 & 245 & 153 & & & & Flavonoid \\
\hline Myricetin & 56,8 & 319 & 319 & 301 & 273 & 245 & 217 & 179 & 165 & 153 & Flavonoid \\
\hline Quercetin & 57,1 & 303 & 303 & 285 & 257 & 229 & 201 & 165 & 153 & 137 & Flavonoid \\
\hline Quercetin-3-glucoside & 57,5 & 465 & 303 & & & & & & & & Flavonoid \\
\hline Isorhamnetin & 58,4 & 317 & 302 & 285 & 274 & 257 & 245 & 229 & 153 & & Flavonoid \\
\hline $\begin{array}{l}\text { Quercetin-3-Rhamnoside } \\
\text { (Quercitrin) }\end{array}$ & 59,8 & 449 & 303 & 287 & & & & & & & Flavonoid \\
\hline
\end{tabular}

B

\begin{tabular}{|c|c|c|c|c|c|c|c|c|c|c|c|c|c|}
\hline \multirow{2}{*}{\begin{tabular}{|r|} 
Compounds \\
Gallocatechin \\
\end{tabular}} & \multirow{2}{*}{\begin{tabular}{|c|}
$\begin{array}{c}\text { Retention } \\
\text { Time } \\
\text { (min) }\end{array}$ \\
48,9 \\
\end{tabular}} & \multirow{2}{*}{$\begin{array}{c}{[\mathbf{M}-\mathbf{H}]^{-}} \\
(\mathrm{m} / z) \\
305\end{array}$} & \multicolumn{10}{|c|}{ Fragments (MS2) } & \multirow{2}{*}{\begin{tabular}{|c|} 
Class \\
Flavonoid
\end{tabular}} \\
\hline & & & 305 & 219 & 167 & 125 & & & & & & & \\
\hline$(+)$-Epicatechin & 51,1 & 289 & 289 & 271 & 245 & 221 & 203 & 188 & 175 & 151 & 137 & 125 & Flavonoid \\
\hline Myricetin-3-Galactoside & 56,2 & 479 & 479 & 316 & 287 & 271 & & & & & & & Flavonoid \\
\hline Quercetin-3-glucoside & 57,6 & 463 & 463 & 300 & & & & & & & & & Flavonoid \\
\hline $\begin{array}{c}\text { Quercetin-3-Rhamnoside } \\
\text { (Quercitrin) }\end{array}$ & 58,8 & 447 & 447 & 300 & 284 & & & & & & & & Flavonoid \\
\hline Isorhamnetin-3-Rutinoside & 59,1 & 623 & 623 & 315 & & & & & & & & & Flavonoid \\
\hline Isorhamnetin-3-Glucoside & 59,5 & 477 & 477 & 315 & & & & & & & & & Flavonoid \\
\hline
\end{tabular}

The bactericidal activity detected in the alcoholic extract of $L$. apiculata against $S$. aureus was significantly more effective than for $K$. pneumoniae. This is probably due to the composition of the outer membrane of both bacteria. According to Pitout and Laupland [29] Gram-negative bacteria are more resistant to the extracts than Grampositive bacteria, because they have hydrophilic polysaccharide chains, which act as a barrier against extracts or essential oils.
Several studies suggest that the mechanism of action of some antimicrobial compounds, such as phenolic compounds, involves damage to both, wall and bacterial cell membrane, which facilitates the leaking of intracellular constituents like proteins, inorganic ions and several enzymes from the cells, triggering a permanent cell damage [30].

The phenolic compounds such as Epicatechin, Myricetin, Quercetin, 
Isorhamnetin and Gallocatechin detected in L. apiculata are widely accepted as medicinally important compounds [31]. Flavonoids interfere with specific intracellular or surface enzymes and many bacterial virulence factors such as toxins, enzymes and signal receptors [32], which could explain the bacteriostatic activity of the extract against MRSA. Previous studies have reported that many medicinal plants containing flavonoids are widely used in traditional medicine for the treatment of human diseases. Flavonoids have been reported to exhibit a variety of important biological activities, including antioxidant properties, inhibition of histamine release and activities of several enzymes [33-35]. More importantly, it has also been reported antimicrobial activity; for example, flavonoids have been found to be effective against Gram-positive bacteria [36]. Another study revealed bacteriostatic activity in several flavonoids tested separately, confirming that quercetin was the most effective inhibitor [37]. In addition, when flavonoids are used in combination with antibiotics show synergistic effects against strain bacterial [30].

This study may not be adequate to suggest a potential new antibiotic agent, considering that antibacterial activity was observed at higher concentrations than those reported in other plant extracts. However, this approach should be considered as a preliminary step to find out new promising molecules with antibacterial activity and to unravel their possible mechanism of microorganism inhibition. Further studies are still needed to assess the influence of different portions of the plant extracts including flowers, leaves or stems, on the bacterial growth rate and as well the evaluation of possible synergistic effects with antibiotics or other medicinal plant extracts.

\section{Conclusion}

Luma apiculata has antibacterial activity against standard multidrug-resistance strains of $S$. aureus and $K$. pneumoniae. The bactericidal activity detected in the alcoholic extract of $L$. apiculata against $S$. aureus was more effective than for $K$. pneumoniae. Flavonoids were the principal compounds detected in the ethanolic extract of $L$. apiculata.

\section{Authors' contributions}

Conceived and designed the experiments: FF Treulen, GE Salcedo \& EA Paz, Performed the experiments: GE Salcedo, FI Garrido \& CE Morales, Analyzed the data: FF Treulen, FI Garrido \& CE Morales, Contributed reagents/ materials/ analysis tools: $\mathrm{RN}$ Felmer, Wrote the paper: FF Treulen, EA Paz \& RN Felmer.

\section{Acknowledgments}

This work was funded by the Research and Development Fund of the Universidad Mayor (project \#100733).

\section{References}

1. Kang CI \& Song JH (2013). Antimicrobial resistance in Asia: Current epidemiology and clinical implications. Infect Chemother 45: 22-31.

2. WHO (2014). Antimicrobial resistance. Global report on surveillance. World Heal Organ 61: 383-394.

3. Rice LB (2010). Progress and Challenges in Implementing the Research on ESKAPE Pathogens. Infect Control Hosp Epidemiol 31: S7-S10.

4. Grundmann H, Aanensen DM, Van Den Wijngaard CC, Spratt BG, Harmsen D \& Friedrich AW (2010). Geographic distribution of Staphylococcus aureus causing invasive infections in Europe: A molecular-epidemiological analysis. PLoS Med 7(1): e1000215.

5. Holden MTG, Hsu L, Kurt K, Weinert LA, Mather AE, Harris SR, Strommenger B, Layer F, Witte W, de Lencastre H, Skov R, Westh H, Zemlickova H, Coombs G, Kearns AM, Hill R, Edgeworth J, Gould 
L, Gant V, Cooke J, Edwards GF, McAdam PR, Templeton KE, McCann A, Zhou Z, Castillo-Ramírez S, Feil EJ, Hudson LO, Enright MC, Balloux F, Aanensen DM, Spratt BG, Fitzgerald JR, Parkhill J, Achtman M, Bentley SD \& Nubel U. (2013). A genomic portrait of the emerfences, evolution, and global spread of methicillin-resistant Staphylococcus aureus. Genome Res 23: 653-664.

6. Paczosa MK \& Mecsas J (2016). Klebsiella pneumoniae: Going on the Offense with a Strong Defense. Microbiol Mol Biol Rev 80: 629-661.

7. Anderson KF, Lonsway DR, Rasheed JK \& Patel JB (2007). Evaluation of methods to identify the Klebsiella pneumoniae carbapenemase in Enterobacteriaceae. $J$ Clin Microbiol 45: 2723-2725.

8. Theuretzbacher U (2017). Global antimicrobial resistance in Gram-negative pathogens and clinical need. Curr Opin Microbiol 39: 106-112.

9. Negi PS (2012). Plant extracts for the control of bacterial growth: Efficacy, stability and safety issues for food application. Int J Food Microbiol 156: 717.

10. Gonçalves MJ, Cavaleiro C, Da Cunha AP \& Salgueiro LR (2006). Chemical composition and antimicrobial activity of the commercially available oil of Luma chequen (Molina) A. Gray. J Essent Oil Res 18: 108-110.

11. Hussain AI, Anwar F, Hussain Sherazi ST \& Przybylski R (2008). Chemical composition, antioxidant and antimicrobial activities of basil (Ocimum basilicum) essential oils depends on seasonal variations. Food Chem 108: 986995.

12. Lorca MA, Canales CL, Valenzuela CG \& Berner CMB (2012). Antimicrobial effects of extracts from Chilean plants of Lauraceae and Atherospermataceae families. Rev Cuba Plantas Med 17: 7383.
13. Massardo F \& Rozzi R (1996). Valoración de la biodiversidad: Usos medicinales de la flora nativa chilena. Cienc y Ambient 12:76-81.

14. Ministerio de Salud. Gobierno de Chile. (2010). MHT: Medicamentos Herbarios Tradicionales, pp 6-232.

15. Theoduloz C, Pacheco P \& SchmedaHirschmann G (1991). Xanthine oxidase inhibitory activity of Chilean Myrtaceae. $J$ Ethnopharmacol 33: 253-255.

16. De Mösbach EW (1992). Botánica indígena de Chile, pp 68.

17. Falkenberg SS, Tarnow I, Guzman A, Mølgaard P \& Simonsen HT (2012). Mapuche herbal medicine inhibits blood platelet aggregation. Evid Based Complement Alternat Med 2012: 1-9.

18. Simirgiotis MJ, Bórquez J \& SchmedaHirschmann G (2013). Antioxidant capacity, polyphenolic content and tandem HPLC-DAD-ESI/MS profiling of phenolic compounds from the South American berries Luma apiculata and L. chequén. Food Chem 139: 289-299.

19. Clinical and Laboratory Standards Institute (2018). M100 Performance Standards for Antimicrobial Susceptibility Testing, 27th.

20. Klančnik A, Piskernik S, Jeršek B \& Možina SS (2010). Evaluation of diffusion and dilution methods to determine the antibacterial activity of plant extracts. $J$ Microbiol Methods 81: 121-126.

21. Fisher K \& Phillips CA (2006). The effect of lemon, orange and bergamot essential oils and their components on the survival of Campylobacter jejuni, Escherichia coli O157, Listeria monocytogenes, Bacillus cereus and Staphylococcus aureus in vitro and in food systems. J Appl Microbiol 101: 1232-1240.

22. Premanandh J, Samara BS \& Mazen AN (2016). Race Against Antimicrobial Resistance Requires Coordinated Action An Overview. Front Microbiol 6: 1536.

23. Carrillo ML, Castillo LN \& Mauricio R (2011). Evaluación de la Actividad Antimicrobiana de Extractos de Propóleos 
de la Huasteca Potosina (México). Inf Tecnol 22: 21-28.

24. Bruschi ML, Franco SL \& Gremião MPD (2003). Application of an HPLC Method for Analysis of Propolis Extract. J Liq Chromatogr Relat Technol 26: 37-41.

25. Bayala B, Bassole IHN, Maqdasy S \& Becerra Allende CJ (2018). Cymbopogon citratus and Cymbopogon giganteus essential oils have cytotoxic effects on tumor cell cultures. Identification of citral as a new putative anti-proliferative molecule. BMC Complement Altern Med 74: 1-12.

26. Semwal DK, Semwal RB, Combrinck S $\&$ Viljoen A (2016). Myricetin: A dietary molecule with diverse biological activities. Nutrients 8: 1-31.

27. Ramos G, Frutos P, Giráldez FJ \& Mantecón AR (1998). Los compuestos secundarios de las plantas en la nutrición de los herbívoros. Arch Zootec 47: 597620.

28. Avello Lorca CM, Bittner Berner CM \& Becerra Allende CJ (2013). Efectos antibacterianos de extractos de especies del genero Ugni que crecen en Chile. Rev Cuba Plantas Med 18: 247-257.

29. Pitout JD \& Laupland KB (2008). Extended-spectrum $\quad \beta$-lactamaseproducing Enterobacteriaceae: an emerging public-health concern. Lancet Infect Dis 8: 159-166.

30. Amin MU, Khurram M, Khan TA, Faidah HS, Shah ZU, Rahman SU, Haseeb A, Ilyas M, Ullah N, Khayam SMU \& Iriti M (2016). Effects of luteolin and quercetin in combination with some conventional antibiotics against methicillin-resistant Staphylococcus aureus. Int J Mol Sci 17: 1-16.
31. Dai J \& Mumper RJ (2010). Plant phenolics: Extraction, analysis and their antioxidant and anticancer properties. $\mathrm{Mol}$ 15: 7313-7352.

32. Cushnie TPT \& Lamb AJ (2011). Recent advances in understanding the antibacterial properties of flavonoids. Int $J$ Antimicrob Agents 38: 99-107.

33. Budzianowski J, Korzeniowska K, Chmara E \& Mrozikiewicz A (1999). Microvascular protective activity of flavonoid glucuronides fraction from Tulipa gesneriana. Phytother Res 13: 166168.

34. Bastianetto S, Zheng WH \& Quirion R (2000). The Ginkgo biloba extract (EGb 761) protects and rescues hippocampal cells against nitric oxide-induced toxicity: Involvement of its flavonoid constituents and protein kinase C. J Neurochem 74: 2268-2277.

35. Wenzel U, Kuntz S, Brendel MD \& Daniel H (2000). Dietary Flavone Is a Potent Apoptosis Inducer in Human Colon Carcinoma Cells Dietary Flavone Is a Potent Apoptosis Inducer in Human Colon Carcinoma Cells. Cancer Res 60: 38233831.

36. Lin RD, Chin YP \& Lee MH (2005). Antimicrobial Activity of Antibiotics in Combination with Natural Flavonoids against Clinical Extended-Spectrum (ESBL)-producing Klebsiella pneumoniae $\beta$-Lactamase. Phyther Res 19: 612-617.

37. Moon SH, Lee KA, Park KK \& Paik HD (2011). Antimicrobial Effects of Natural Flavonoids and a Novel Flavonoid, 7-OButyl Naringenin, on Growth of Meatborne Staphylococcus aureus Strains. Korean J Food Sci Anim Resour 31: 413419. 